\title{
Time-Spatial Features of Mix El Niño
}

\author{
Zhiyuan Zhang ${ }^{1,2,3}$ and Gen $\mathrm{Li}^{1,2, * \mathbb{D}}$ \\ 1 Key Laboratory of Marine Hazards Forecasting, Ministry of Natural Resources, College of Oceanography, \\ Hohai University, Nanjing 210098, China; 20190936@hhu.edu.cn \\ 2 Southern Marine Science and Engineering Guangdong Laboratory (Zhuhai), Zhuhai 519082, China \\ 3 State Key Laboratory of Loess and Quaternary Geology, Institute of Earth Environment, \\ Chinese Academy of Sciences, Xi'an 710000, China \\ * Correspondence: ligen@hhu.edu.cn
}

Citation: Zhang, Z.; Li, G.

Time-Spatial Features of Mix El Niño. Atmosphere 2021, 12, 476. https:/ / doi.org/10.3390/atmos12040476

Academic Editors: Youmin Tang,

Xiaoxiao Tan, Satyaban Bishoyi Ratna, Bryan C. Weare and Anthony R. Lupo

Received: 10 February 2021

Accepted: 6 April 2021

Published: 9 April 2021

Publisher's Note: MDPI stays neutral with regard to jurisdictional claims in published maps and institutional affiliations.

Copyright: (c) 2021 by the authors. Licensee MDPI, Basel, Switzerland. This article is an open access article distributed under the terms and conditions of the Creative Commons Attribution (CC BY) license (https:// creativecommons.org/licenses/by/ $4.0 /)$.

\begin{abstract}
The diversity of El Niño is a critical field of the climate research. The eastern Pacific (EP) and central Pacific (CP) types of El Niño have been identified in the previous studies. However, the extreme El Niño event that occurred in 2015-2016 is quite different from both the EP and CP El Niño events. The sea surface temperatures anomalies (SSTA) for this event widely spread in both the central and eastern Pacific and have a small zonal gradient in the central-eastern Pacific. Many researchers regarded this event as a mixed type of El Niño. Using the regression-EOF method, the Mix El Niño pattern is extracted from the tropical Pacific SSTA field during the period from 1900 to 2019. Here, we reveal that the Mix El Niño is a very usual rather than a new type of El Niño, it is just that the EP and CP El Niño events are more frequent since the 1980s, while the Mix El Niño events frequently appear before the 1980s. The time-spatial features of the Mix El Niño are further investigated. The results demonstrate a unique westward propagation of the maximum SSTA for the Mix El Niño from the far eastern Pacific to the central Pacific. In contrast, the SSTA center is locked in the far eastern Pacific region for the EP El Niño and the central Pacific region for the CP El Niño. The evolutions of subsurface ocean temperature anomalies and sea surface height anomalies are also examined to support this. The ocean-atmosphere interaction plays an important role in the evolution of the Mix El Niño. The anomalous atmospheric Walker circulation for the Mix El Niño is mainly in the western and central Pacific as well as very weak in the eastern Pacific. In contrast, there are significant westerlies/easterlies in the eastern Pacific for the EP/CP El Niño. The small gradient of SSTA in the central-eastern Pacific for the Mix El Niño leads to weak zonal wind anomalies, which further weaken the zonal gradient of SSTA. All this suggests that the Mix El Niño is not unusual and fundamentally different from the EP and CP El Niño with important implications for global climate effects.
\end{abstract}

Keywords: mix El Niño; Eastern Pacific El Niño; Central Pacific El Niño; El Niño diversity; timespatial features

\section{Introduction}

El Niño is the strongest signal in annual time-scale for the climate change with anomalous warming sea surface temperature anomalies (SSTA) in tropical central and eastern Pacific region [1]. The El Niño events are generally accompanied with strong oceanatmosphere coupled interaction and have great impacts on the global climate system through atmospheric teleconnection [2-5]. The wide research on El Niño is from the 1980s [6], to be exact, the 1982-1983 extreme El Niño. With the emergence of more El Niño events, it is found that there are great differences among them [7]. As the diversity of El Niño is so pronounced, only one model cannot describe the El Niño adequately [8]. The 1997-1998 El Niño is the second extreme El Niño event after 1982-1983 El Niño. These two El Niño events are very similar in the time-spatial features, evolution, and impacts on climate. As the SSTA during these two events are mainly in the eastern Pacific region, this 
type of El Niño is called as EP El Niño [9]. In some researches, the EP El Niño is also called as cold tongue El Niño [10] or traditional El Niño [11]. However, for some El Niño events, the SSTA are mainly located in the central Pacific, e.g., 2004-2005 El Niño. Many El Niño events that with the warming center in the central Pacific occurred since 1980s [12]. This type of El Niño is generally called as CP El Niño [9] (or warm pool El Niño [10], El Niño Modoki [11], and Dateline El Niño [13]). The evolution and climate effects of CP El Niño are also quite different from the EP El Niño [14-16].

Ashoke et al. [11] applied Empirical Orthogonal Functions (EOF) analysis on the tropical SSTA field from 1979 to 2006 and extracted the first two modes. The first mode is the EP type of El Niño, while the second mode is the CP type of El Niño (Modoki El Niño is named in their research). The characters of CP El Niño are deeply investigated in the research and their results demonstrate that the $\mathrm{CP}$ El Niño is an independent El Niño from the traditional EP El Niño, which is further confirmed in the research of Li et al. [17]. The EP El Niño is a dipole mode with cooling in the western Pacific and warming in the eastern Pacific while the CP El Niño is a tripolar mode with cooling in both eastern Pacific and far eastern Pacific but warming in central Pacific [18,19]. Yu and Kao [9] believe the CP El Niño pattern is disturbed by the EP El Niño pattern in basic EOF analysis and proposed the regression-EOF method (see Data and Methods) to extract EP and CP types of El Niño, respectively. The regression-EOF method subtracts SSTA that highly related to the NINO4 and NINO1 +2 indices, respectively, from the original SSTA field and then apply EOF analysis on the two processed SSTA field, respectively. The first modes of two EOF analyses are EP and CP El Niño pattern, respectively. Ren and Jin [12] noticed the EP and CP El Niño could be easily characterized by the combination of NINO3 and NINO4 indices and proposed a couple of El Niño indices, Niño index for Cold Tongue/Warm Pool El Niño $\left(\mathrm{N}_{\mathrm{CT}} / \mathrm{N}_{\mathrm{WP}}\right)$, to characterize two types of El Niño, respectively.

Besides the EP and CP El Niño, there are some El Niño events with widely spread of SSTA over both central and eastern Pacific and small zonal gradient in central-eastern Pacific. These El Niño events are called as Mix El Niño [10,20-22], since they cannot be classified properly as EP or CP El Niño. Chen et al. [20] extracted three clusters of El Niño by the fuzzy clustering method. The cluster 1 and 2 are EP and CP types of El Niño and the cluster 3 has a widely spread of SSTA in both central and eastern Pacific which could be regarded as the Mix El Niño. Yu and Kim [21] further distinguished Mix El Niño from EP and CP El Niño by developing a pattern correlation method. Zhang et al. [22] investigated EP, CP, and Mix El Niño by building a unified El Niño index, which could distinguish Mix El Niño from EP and CP El Niño. These studies all show that the Mix El Niño is very common type of El Niño. The 2015-2016 El Niño is the third extreme El Niño after 1982-1983 and 1997-1998 El Niño events based on the observation data [23]. However, the 2015-2016 El Niño shows quite different physical features and climate effects from the first two extreme strong El Niño events and this El Niño event is also quite different from the CP El Niño [23-27]. The 2015-2016 El Niño is widely regarded as a mixed type of El Niño [28-30]. Therefore, the research of Mix El Niño becomes of more significance owing to its potential impacts on global climate.

The reason we study the El Niño diversity is that the different types of El Niño can lead to different impacts to climate. A large number of studies have revealed the unique impacts of EP and CP El Niño. For example, the tropical rainfall patterns that related to EP and CP El Niño are quite different. The center of the anomalous precipitation is around dateline for EP El Niño, while it moves westward to around $165^{\circ} \mathrm{E}$ for $\mathrm{CP} \mathrm{El}$ Niño $[7,10]$. The extratropical climate is also affected differently by two types El Niño via the atmospheric teleconnections. For example, the frequency and tracks of North Atlantic cyclones during EP and CP El Niño are quite different [31]. However, the impact of Mix El Niño on climate system is still not well understood. To improve the understanding of Mix El Niño impacts and related mechanisms, it is essential to study the time-spatial features of Mix El Niño. In this research, we investigated the unique time-spatial features, evolutions, ocean-atmosphere coupled interaction of the mixed type of El Niño. 
The rest of this paper is organized as follows: In Section 2, we introduced the data and method used in this search. In Section 3, we extracted Mix El Niño pattern from the SSTA field during 1900 to 2019 using the regression EOF method. Then, we analyzed the decadal features of three types of El Niño in Section 4. In Section 5, we investigated the evolution and ocean-atmosphere coupled interaction of Mix El Niño. The summary and discussion are in Section 6.

\section{Data and Method}

\subsection{Data}

Multisource observation datasets were used in this research. The specific information of these datasets is shown in Table 1. It should be noted that we combined two wind datasets to cover the research period from 1900 to 2019 (NOAA-CIRES data for 1900 to 1948 and NCEP data for 1948 to 2019) with a unified $2^{\circ} \times 2^{\circ}$ horizontal resolution.

Table 1. Information of the datasets used in this study.

\begin{tabular}{|c|c|c|}
\hline Dataset Name & Coverage & Download Website \\
\hline $\begin{array}{l}\text { Hadley Centre Sea Ice and Sea Surface } \\
\text { Temperature dataset (HadISST) [32] }\end{array}$ & $\begin{array}{l}1^{\circ} \times 1^{\circ} \text { horizontal resolution } \\
1870 \text {-present }\end{array}$ & $\begin{array}{l}\text { https://www.metoffice.gov.uk/ } \\
\text { hadobs/hadisst/ }\end{array}$ \\
\hline $\begin{array}{l}\text { EN4: quality controlled subsurface ocean } \\
\text { temperature and salinity profiles and } \\
\text { objective analyses (version } 4.2 .1 \text { ) from the } \\
\text { Met Office Hadley Centre } \\
\text { observation datasets [33] }\end{array}$ & $\begin{array}{l}1^{\circ} \times 1^{\circ} \text { horizontal resolution and } 42(20) \\
\text { levels from subsurface depth } 5 \mathrm{M} \text { to } 5350 \mathrm{M} \\
(315 \mathrm{M}) \\
1900-\text { present }\end{array}$ & $\begin{array}{l}\text { https://www.metoffice.gov.uk/ } \\
\text { hadobs/en4/download-en4-2-1.html }\end{array}$ \\
\hline $\begin{array}{l}\text { Reanalysis Data NCEP monthly pressure } \\
\mathrm{u} \text {-wind and vertical wind [34] }\end{array}$ & $\begin{array}{l}2.5^{\circ} \times 2.5^{\circ} \text { horizontal resolution and } 10 \\
\text { vertical levels from } 1000 \text { to } 200 \mathrm{hPa} \\
1948 \text {-present }\end{array}$ & $\begin{array}{l}\text { https://psl.noaa.gov/data/gridded/ } \\
\text { data.ncep.reanalysis.pressure.html }\end{array}$ \\
\hline $\begin{array}{l}\text { Monthly NOAA-CIRES 20th Century } \\
\text { Reanalysis V2c [35] }\end{array}$ & $\begin{array}{l}2^{\circ} \times 2^{\circ} \text { horizontal resolution and } 24 \\
\text { vertical levels from } 1000 \text { to } 10 \mathrm{hPa} \\
1851-2014\end{array}$ & $\begin{array}{l}\text { https://psl.noaa.gov/data/gridded/ } \\
\text { data.20thC_ReanV2c.html }\end{array}$ \\
\hline $\begin{array}{l}\text { GPCP Version } 2.3 \text { Combined } \\
\text { Precipitation Dataset [36] }\end{array}$ & $\begin{array}{l}2.5^{\circ} \times 2.5^{\circ} \text { horizontal resolution } \\
1979 \text {-present }\end{array}$ & $\begin{array}{l}\text { https://psl.noaa.gov/data/gridded/ } \\
\text { data.gpcp.html }\end{array}$ \\
\hline
\end{tabular}

\subsection{Index}

Many indices have been proposed to characterize EP and CP El Niño. The specific information and brief description of some common indices are shown in Table 2. In this study, we choose $\mathrm{N}_{\mathrm{CT}} / \mathrm{N}_{\mathrm{WP}}$ for the research, which has been proved to be a good pair of indices to characterize and distinguish EP and CP El Niño [12]. The EMI (Improved El Nino Modoki Index, IEMI)/NINO3 and EP/CP El Niño Subsurface index (EPSI/CPSI) are also good pairs of indices for EP and CP El Niño [17,37,38]. We have used these indices to examine the main results of this work and the results are similar to that of $\mathrm{N}_{\mathrm{CT}} / \mathrm{N}_{\mathrm{WP}}$. To get rid of the Mix El Niño signal that mixed in $\mathrm{N}_{\mathrm{CT}}$ and $\mathrm{N}_{\mathrm{WP}}$ indices, we multiply the $\mathrm{N}_{\mathrm{CT}}$ and $\mathrm{N}_{\mathrm{WP}}$ by the absolute value of TNI (which represents the zonal SSTA gradient in central-eastern Pacific). The EP El Niño index (EPI) and CP El Niño index (CPI) are defined as follows

$$
\left\{\begin{array}{c}
E P I=|T N I| * N_{C T} \\
C P I=|T N I| * N_{W P}
\end{array} .\right.
$$

By this transformation, the value of the EPI (CPI) will be higher than the $\mathrm{N}_{\mathrm{CT}}\left(\mathrm{N}_{\mathrm{WP}}\right)$ during EP (CP) El Niño events, while lower than the $\mathrm{N}_{\mathrm{CT}}\left(\mathrm{N}_{\mathrm{WP}}\right)$ during Mix El Niño events.

\subsection{Regression-EOF}

Yu and Kao [9] first subtracted the anomalies regressed with the NINO4 and NINO1 + 2 from the original SSTA field, respectively, then applied EOF analysis on the two processed SSTA fields, respectively, and finally extracted two leading modes, which are EP and CP El 
Niño, respectively. As the SSTA of Mix El Niño widely spread in both central and eastern Pacific. With the basic EOF method, most of the Mix El Niño events will be forcibly divided into EP or CP category, and as a result, the mixed pattern can hardly be extracted. In this research, the Mix El Niño has been successfully extracted by the method similar with Yu and Kao [9].

Table 2. Definitions of the El Niño indices used in this study.

\begin{tabular}{|c|c|c|}
\hline Index Name & Definition & Brief Description \\
\hline $\begin{array}{l}\text { NINO1 }+2 \\
\text { NINO3 } \\
\text { NINO4 } \\
\text { NINO3.4 }\end{array}$ & $\begin{array}{l}\text { Area-averaged SSTA over }\left(90^{\circ} \mathrm{W}-80^{\circ} \mathrm{W}, 10^{\circ} \mathrm{S}-0^{\circ}\right) \\
\text { Area-averaged SSTA over }\left(150^{\circ} \mathrm{W}-90^{\circ} \mathrm{W}, 5^{\circ} \mathrm{S}-5^{\circ} \mathrm{N}\right) \\
\text { Area-averaged SSTA over }\left(160^{\circ} \mathrm{E}-150^{\circ} \mathrm{W}, 5^{\circ} \mathrm{S}-5^{\circ} \mathrm{N}\right) \\
\text { Area-averaged SSTA over }\left(170^{\circ} \mathrm{W}-120^{\circ} \mathrm{W}, 5^{\circ} \mathrm{S}-5^{\circ} \mathrm{N}\right)\end{array}$ & $\begin{array}{l}\text { Well-known El Niño indices, but } \\
\text { cannot well distinguish different } \\
\text { types of El Niño. }\end{array}$ \\
\hline $\begin{array}{l}\text { Trans-Niño index (TNI) } \\
{[8]}\end{array}$ & $T N I=N I N O 1+2-N I N O 4$ & $\begin{array}{l}\text { An index representing the zonal } \\
\text { SSTA gradient in central-eastern } \\
\text { Pacific region }\end{array}$ \\
\hline $\begin{array}{l}\text { El Niño Modoki index } \\
\text { (EMI) [11] }\end{array}$ & $\begin{array}{l}E M I=[S S T A]_{A}-0.5 *[S S T A]_{B}-0.5 *[S S T A]_{C} \\
\text { The brackets represent the area-averaged SSTA over the region } \\
\mathrm{A}\left(165^{\circ} \mathrm{E}-140^{\circ} \mathrm{W}, 10^{\circ} \mathrm{S}-10^{\circ} \mathrm{N}\right), \mathrm{B}\left(110^{\circ} \mathrm{W}-70^{\circ} \mathrm{W}, 15^{\circ} \mathrm{S}-5^{\circ} \mathrm{N}\right) \text {, } \\
\text { and } \mathrm{C}\left(125^{\circ} \mathrm{E}-145^{\circ} \mathrm{E}, 10^{\circ} \mathrm{S}-20^{\circ} \mathrm{N}\right) \text {, respectively. }\end{array}$ & $\begin{array}{l}\text { An index that is built based on the } \\
\text { zonal tripolar structure of central } \\
\text { Pacific (CP) El Niño pattern derived } \\
\text { by the EOF method. }\end{array}$ \\
\hline $\begin{array}{l}\text { Improved El Niño } \\
\text { Modoki index (IEMI) } \\
\text { [37] }\end{array}$ & $I E M I=3 *[S S T A]_{A}-2 *[S S T A]_{B}-[S S T A]_{C}$ & $\begin{array}{l}\text { An improved index of EMI by } \\
\text { adjusting the proportion of three } \\
\text { items in EMI. }\end{array}$ \\
\hline $\begin{array}{l}\text { Niño index for Cold } \\
\text { Tongue/Warm Pool El } \\
\text { Niño }\left(\mathrm{N}_{\mathrm{CT}} / \mathrm{N}_{\mathrm{WP}}\right)[12]\end{array}$ & $\begin{array}{c}\left\{\begin{array}{c}N C T=N I N O 3-\alpha * \text { NINO4 } \\
N W P=N I N O 4-\alpha * N I N O 3\end{array}\right\} \\
\text { where } \alpha \text { equals } 0.4 \text { when NINO3*NINO4 }>0 \text {, otherwise } \\
\text { equals } 0 .\end{array}$ & $\begin{array}{l}\text { A pair of El Niño index that is built } \\
\text { based on the features of NINO3 and } \\
\text { NINO4 during eastern Pacific (EP) } \\
\text { and CP El Niño. }\end{array}$ \\
\hline $\begin{array}{l}\text { EP/CP El Niño } \\
\text { Subsurface index } \\
\text { (EPSI/CPSI) [38] }\end{array}$ & $\begin{array}{l}\text { Area-averaged SSTA of }\left(90^{\circ} \mathrm{W}-80^{\circ} \mathrm{W}, 5^{\circ} \mathrm{S}-5^{\circ} \mathrm{N}\right. \\
\text { upper } 100 \mathrm{~m}) /\left(160^{\circ} \mathrm{E}-150^{\circ} \mathrm{W}, 5^{\circ} \mathrm{S}-5^{\circ} \mathrm{N}, \text { upper } 100 \mathrm{~m}\right)\end{array}$ & $\begin{array}{l}\text { EP and CP El Niño indices based on } \\
\text { the subsurface ocean temperature } \\
\text { anomalies. }\end{array}$ \\
\hline $\begin{array}{l}\text { Unified Complex El } \\
\text { Niño index (UCEI) [22] }\end{array}$ & $\begin{array}{l}\text { UCEI }=(\text { NINO3 }+ \text { NINO4 })+(N I N O 3-N I N O 4) i=r e^{\theta i} \\
\text { the } r \text { represents the strength of El Niño while the } \theta \text { is used to } \\
\text { determine the type of El Niño as follows: } \\
\left.\qquad \begin{array}{lr}\theta \in\left(15^{\circ}, 90^{\circ}\right) & \text { EP El Nino } \\
\theta \in\left(-15^{\circ}, 15^{\circ}\right) & \text { Mix El Nino } \\
\theta \in\left(-90^{\circ},-15^{\circ}\right) & \text { CP El Nino } \\
\theta \in\left(-165^{\circ},-90^{\circ}\right) & \text { EP La Nina } \\
\theta \in\left(-195^{\circ},-165^{\circ}\right) & \text { Mix La Nina } \\
\theta \in\left(-270^{\circ},-195^{\circ}\right) & \text { CP La Nina }\end{array}\right\}\end{array}$ & $\begin{array}{l}\text { A complex index characterizing EP, } \\
\mathrm{CP} \text {, and Mix El Niño unifiedly, good } \\
\text { at classification of three types of El } \\
\text { Niño but not convenient for some } \\
\text { statistical analysis such as } \\
\text { lead-lag correlation. }\end{array}$ \\
\hline
\end{tabular}

The SSTA of EP El Niño is very strong in the eastern Pacific region and weak in the central Pacific region, while the SSTA of CP El Niño is strong in the central Pacific region and weak in the eastern Pacific region $[9,10]$. Both EP or CP El Niño have strong zonal SSTA gradient in central-eastern Pacific region in mature phase. However, the zonal gradient of SSTA during Mix El Niño is very small. Based on this feature, we first subtracted the anomalies regressed with the time series of the zonal gradient (NINO1 + 2-NINO4, i.e., TNI, which includes the signals of both EP and CP El Niño) from the original SSTA field and then applied EOF analysis on the processed SSTA field.

\subsection{Wavelet Power Spectrum}

The Wavelet Power Spectrum analysis is a common method to analyze the timefrequency features of El Niño. In short, by sliding a Morlet wavelet with a specific width (i.e., period) along the time axis, we can find the El Niño that has the similar period at different points in time axis. By changing the width of the wavelet, we can get the performance of El Niño at different periods. For more information of Wavelet Power 
Spectrum, see: https:/ / paos.colorado.edu/research/wavelets/wavelet1.html (accessed on 7 April 2021).

\section{Mix El Niño Pattern Derived by Regression-EOF Method}

Figure 1a shows the normalized time series of the zonal SSTA gradient in the centraleastern Pacific region from 1900 to 2017. Zonal gradients of 1982-1983 and 1997-1998 (two extreme EP El Niño) are very large, while the 2015-2016 Mix El Niño (with comparable SSTA strength relative to the 1982-1983, 1997-1998 El Niño events) shows a small zonal gradient.

(a) Zonal Gradient

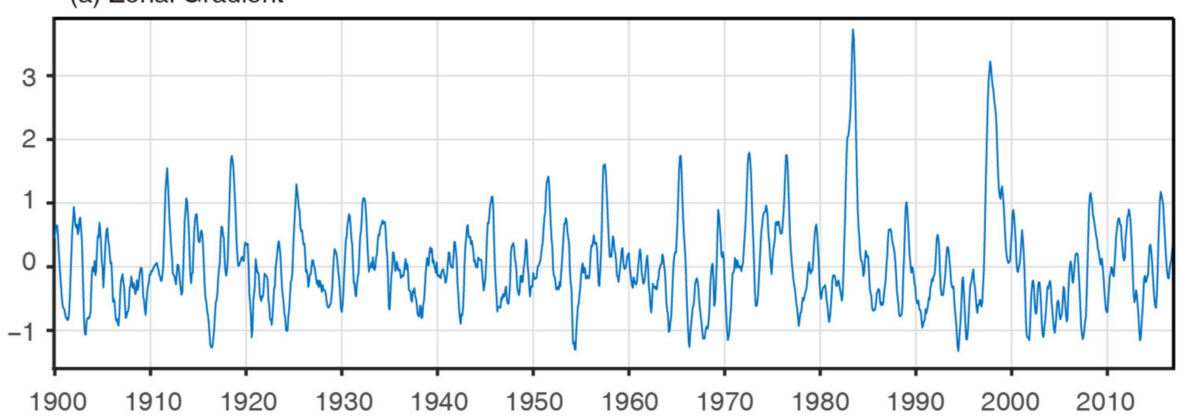

(b) Regression Pattern

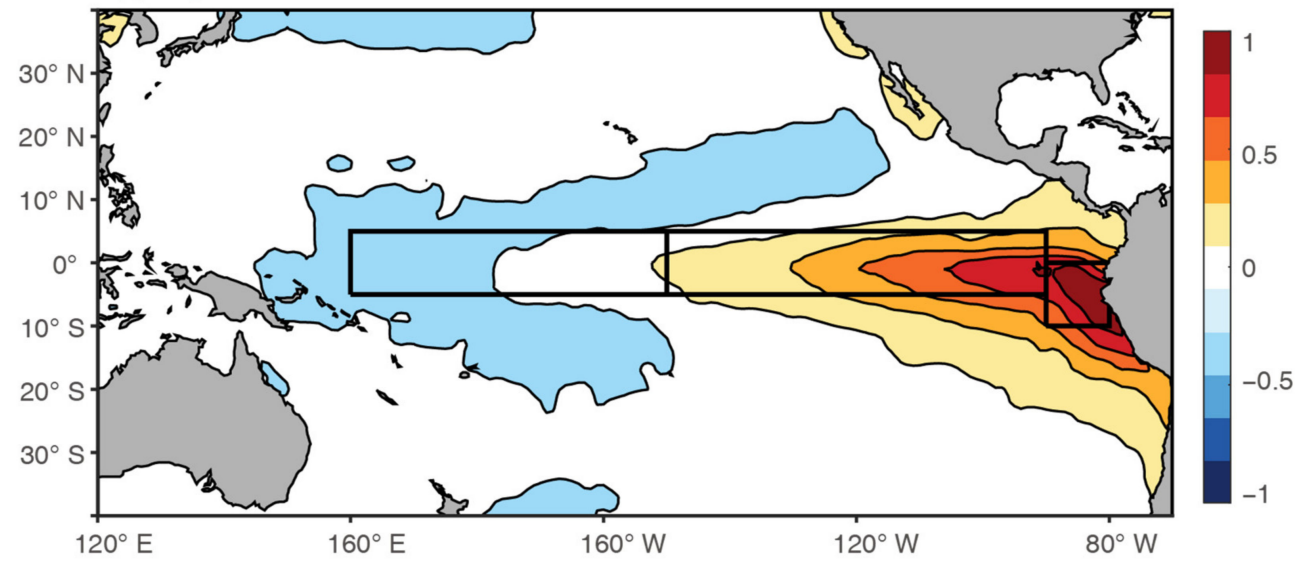

Figure 1. (a) Time series of zonal gradient, defined as NINO1 + 2 - NINO4, smoothed with 7-month running mean, unit: ${ }^{\circ} \mathrm{C}$ and (b) pattern of sea surface temperatures anomalies (SSTA) regressed on the zonal gradient, black boxes indicate NINO4, NINO3, and NINO1 + 2 regions, respectively.

As for CP El Niño, it shows a negative zonal gradient, e.g., the 2004-2005 El Niño event. The regression pattern of the zonal gradient is shown in Figure $1 \mathrm{~b}$. The positive SSTA in the eastern Pacific cold tongue region is the typical EP El Niño pattern with the maximums in NINO1 + 2 region while the negative SSTA with an apparent horseshoe pattern in the western Pacific warm pool region is the typical CP El Niño pattern.

The Mix El Niño pattern is successfully extracted by the regression-EOF method (shown in Figure 2a, which is the first mode and explains $33 \%$ of the total variance). The normalized time series of the principal component of the first EOF mode (PC1, Figure $2 b$ ) will be used to characterize Mix El Niño in this research. It should be noted that even though we have subtracted the SSTA that are highly related to the EP and CP El Niño, the PC1 during 1982-1983 and 1997-1998, two extreme EP El Niño events, is still high. It is reasonable that the SSTA widely extend into central Pacific during these two events and the SSTA distribution is similar to Mix El Niño pattern after removing the EP El Niño signal. Due to their extreme strength, the left Mix El Niño signal is still relatively high. 
(a) EOF 1

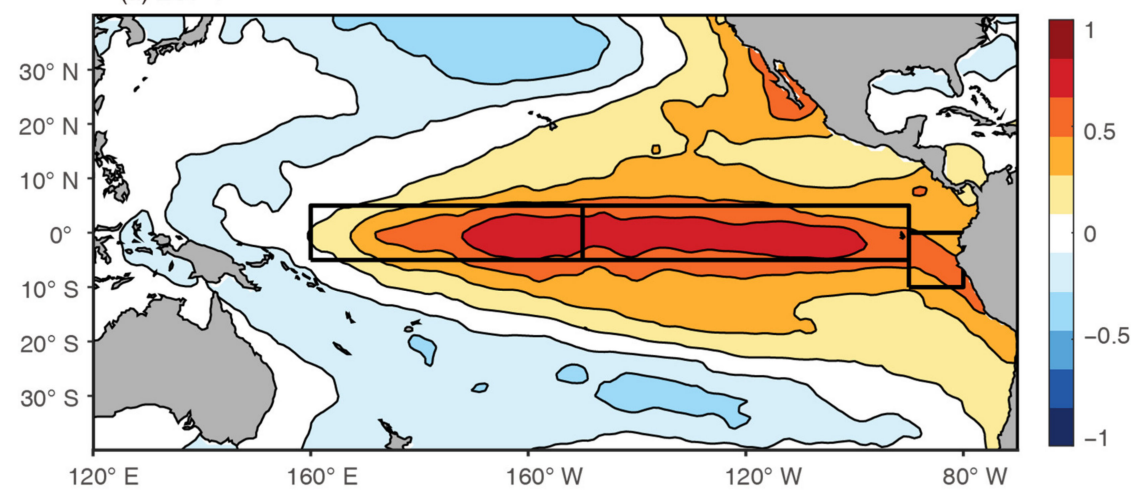

(b) PC1

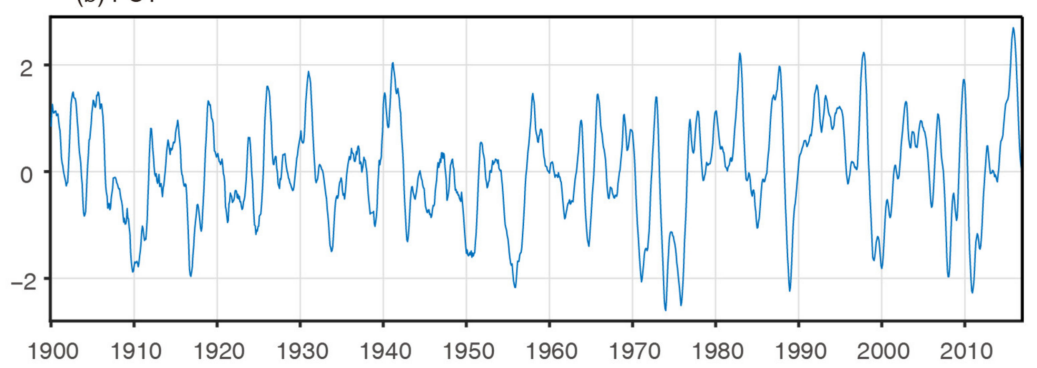

Figure 2. Mode 1 of the Regression-Empirical Orthogonal Functions (EOF) of the tropical Pacific SSTA. (a) Spatial pattern, black boxes indicate NINO4, NINO3, and NINO1 + 2 regions, respectively. (b) normalized and smoothed (7-month running mean) time series of PC1.

\section{Decadal Change of Mix El Niño}

The processed EP and CP indices (see Section 2.2) are shown in Figure 3 as well as the regression patterns of two indices. As the Figure $3 c, d$ demonstrates, the regression patterns of EPI and CPI are closer to the ideal EP and CP El Niño pattern. From this section, we use the EPI and CPI to investigate the characters of EP and CP El Niño as control result.
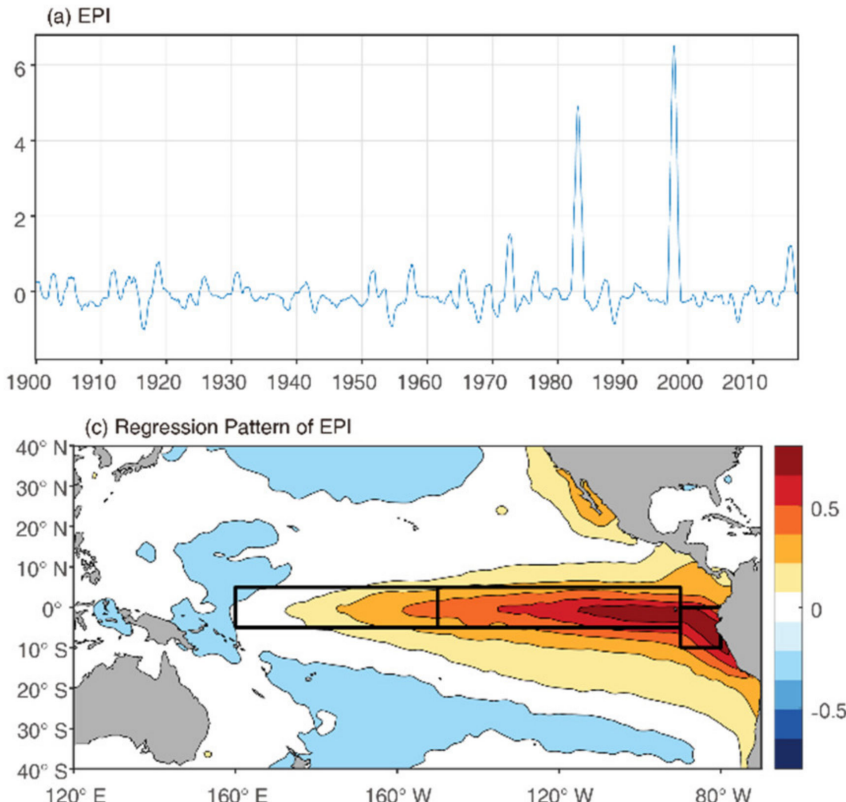
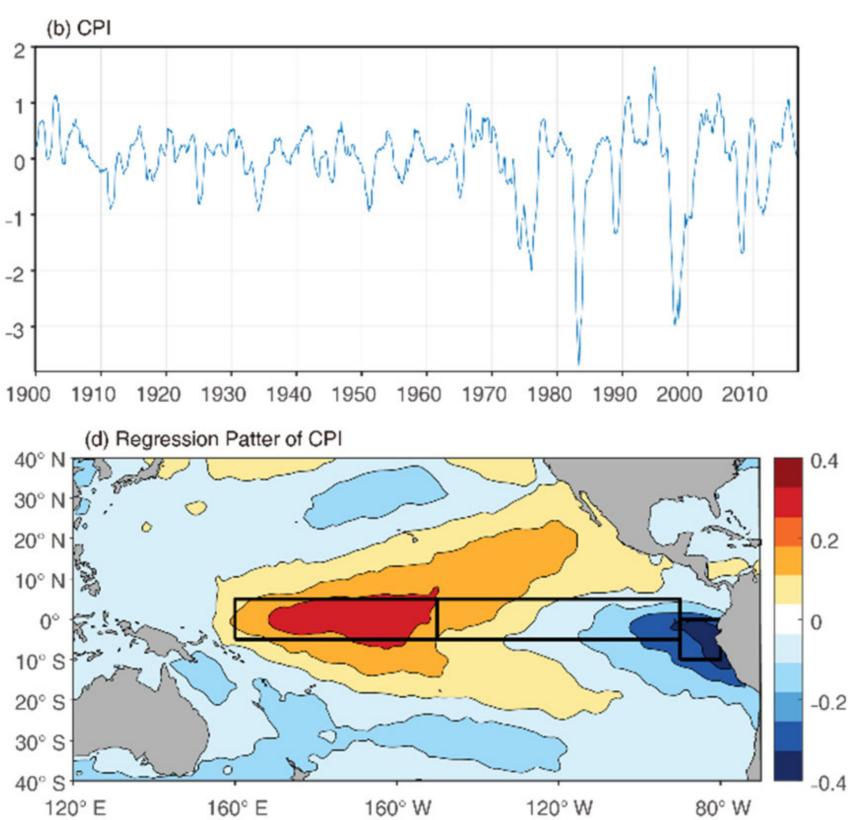

Figure 3. (a,b) Normalized time series of eastern Pacific El Niño index (EPI) and central Pacific El Niño index (CPI) (c,d) regression patterns of SSTA on EPI and CPI, unit: ${ }^{\circ} \mathrm{C}$. Black boxes indicate NINO4, NINO3, and NINO1 + 2 regions, respectively. 
The El Niño' type has a significant decadal change. Many researches have pointed that the CP El Niño occurred frequently since 1980s. The EP El Niño is regarded as a traditional type of El Niño. However, we find that the Mix El Niño is quite more frequently than the EP El Niño before 1980s. During 1900 to 1980, none extreme El Niño occurred. We noticed among these moderate El Niño events, most of them are Mix type according to the determination of the work of Yu and Kim [22]. To further investigate the decadal change of three types of El Niño, we applied power spectrum analysis on PC1 (represents Mix El Niño), EPI (represents EP El Niño), CPI (represents CP El Niño) (Figure 4). We also applied the Wavelet Power Spectrum analysis on $\mathrm{N}_{\mathrm{CT}}$ and $\mathrm{N}_{\mathrm{WP}}$ indices and the results are similar to the EPI and CPI (not shown in figure). As the Figure 4a demonstrates, the occurrence of Mix El Niño is significant (dashed line) during the entire research period while the occurrence of EP and CP El Niño are both significant only since 1980s.
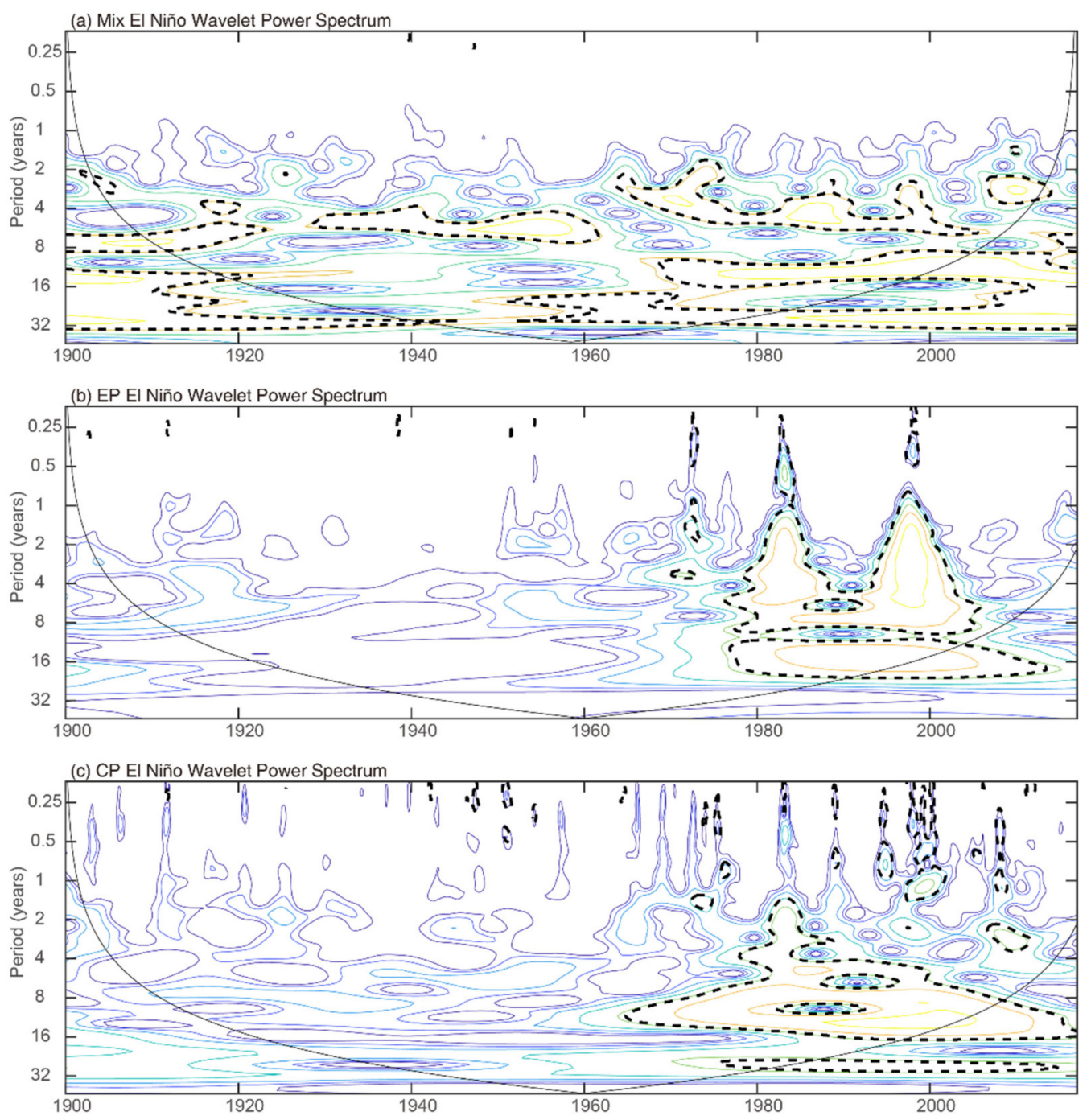

Figure 4. Wavelet Power Spectrum of (a) Mix El Niño (PC1), (b) EPI, and (c) CPI. The contours indicate the power (absolute value squared) of the wavelet transform for the PC1, EPI, and CPI, respectively. The values below the black solid curves are uncertain and the black dashed lines denote the 0.05 significant level.

The 2015-2016 El Niño is quite different from EP type and CP type and has been generally studied as a unique type of El Niño [23-30]. However, from this perspective, the Mix El Niño is a very traditional El Niño even though this type of El Niño did not occur as frequently as EP or CP El Niño during 1980 to 2015. It is hardly to say whether the 
frequency of Mix El Niño will return to the pre-1980s level without a full understanding of the mechanism of Mix El Niño evolution.

\section{Evolution and Ocean-Atmosphere Interaction of Mix El Niño}

Figure 5a shows the lead-lag regression of SSTA on PC1. As the figure demonstrates, the SSTA widely spread in both central and eastern Pacific. However, quite different from EP or CP El Niño, the maximum SSTA have a significant westward propagation. During the developing period (Figure $5 \mathrm{a},-9$, and -6 months lag), the warming center is located in the far eastern Pacific, which is similar to the EP type of El Niño. During the mature period (Figure 5a, 0 lag), the warming center spreads in both central and eastern Pacific while it is relatively weak in the far eastern Pacific, which is the typical feature of the Mix El Niño. When it comes to decaying period, the warming center concentrates in central Pacific while it is weak in the eastern Pacific, which is similar to the CP type of El Niño (Figure 5a; 6 months lag). In contrast, the SSTA are mainly in the eastern Pacific and the maximum SSTA are locked in the far eastern Pacific for the whole process of the EP El Niño (Figure 5b). The two extreme EP El Niño events, 1982-1983 and 1997-1998, also show this feature (not shown). As for CP El Niño (Figure 5c), the warming SSTA are mainly in the central Pacific and the anomalies in eastern Pacific region are very weak. In some CP El Niño events, the far eastern Pacific region even shows an anomalous cooling condition, e.g., the 2004-2005 CP El Niño (not shown). The warming center is locked in the central Pacific with weak zonal propagation.

(a) Mix El Niño

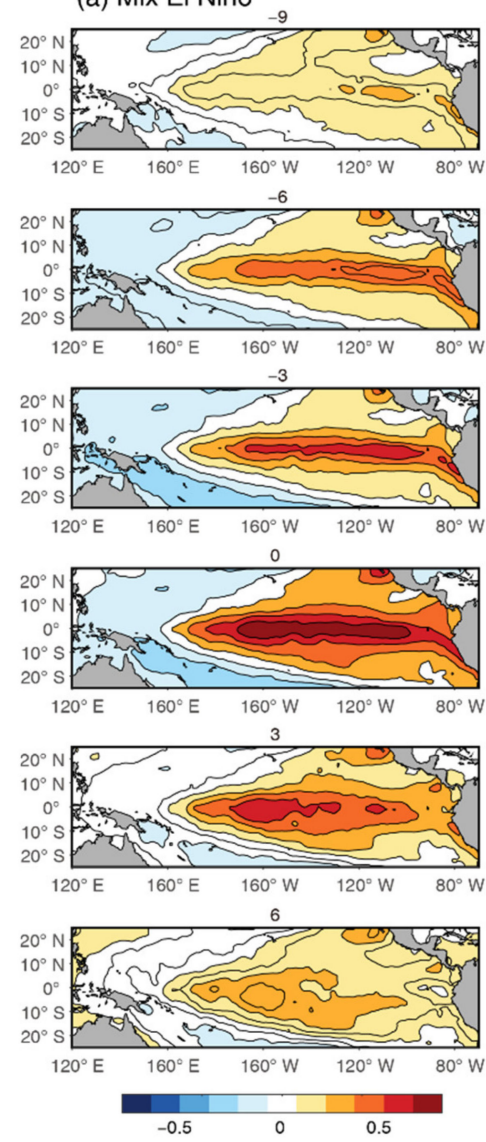

(b) EP EI Niño
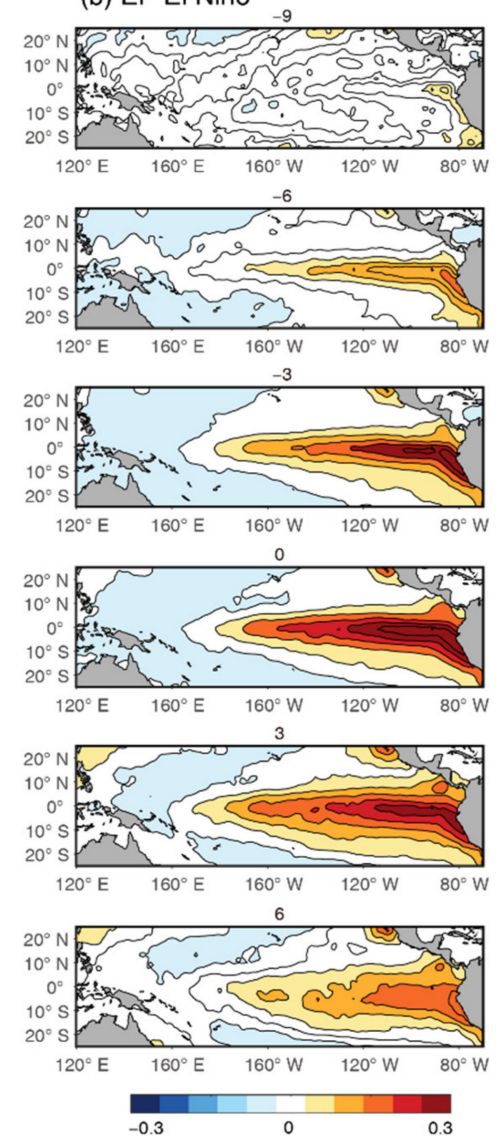

(c) CP El Niño
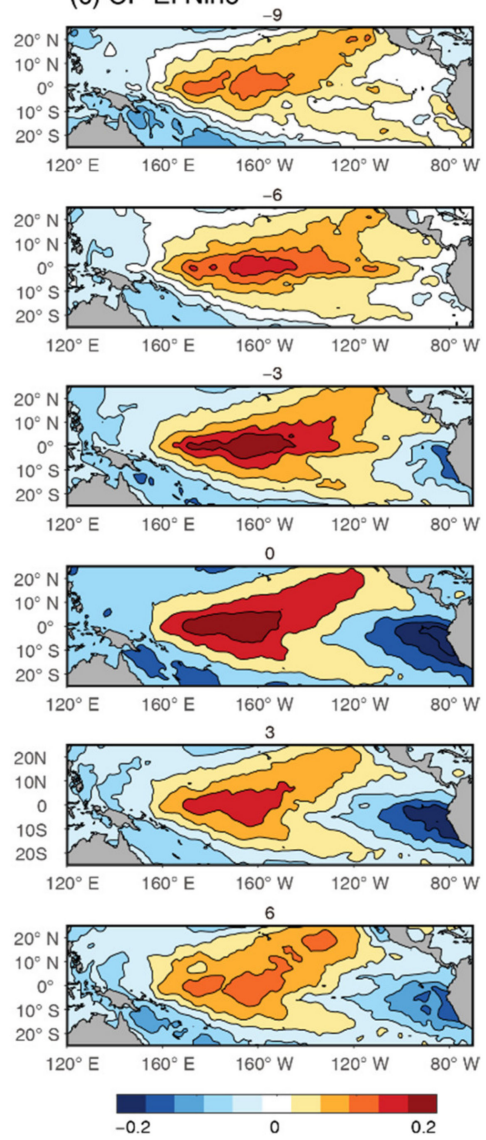

Figure 5. Lead-lag regression coefficient of SSTA on (a) PC1, (b) EPI, and (c) CPI during 1900 to 2019, unit: ${ }^{\circ} \mathrm{C}$. The numbers on the top of each panel indicate the lead-lag months of the index.

To further verify this unique feature of the Mix El Niño, we check the SSTA evolution of the 2015-2016 El Niño event (Figure 6). As the Figure 6 demonstrates, there is a significant 
westward propagation of the SSTA center within this event. The SSTA center is located in the far eastern Pacific in summer and autumn (Figure 6a,b). In winter (Figure 6c), the maximum SSTA are in both central and eastern Pacific and the far eastern Pacific is no longer the center region. Along with the propagating, the SSTA center is mainly located in the central Pacific in spring of the next year (Figure 6d).

(a) 2015 Summer

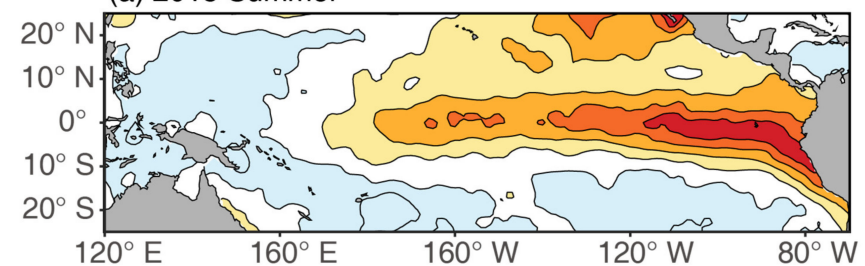

(b) 2015 Autumn

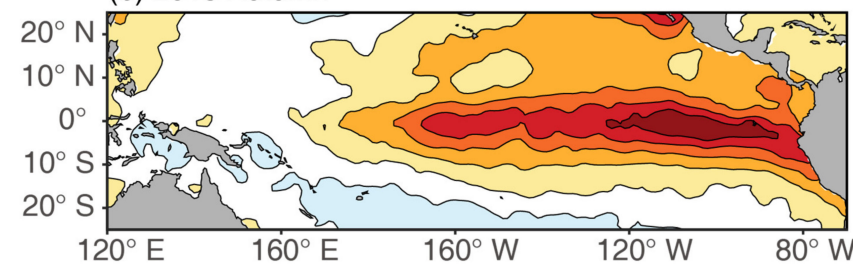

(c) 2015 Winter

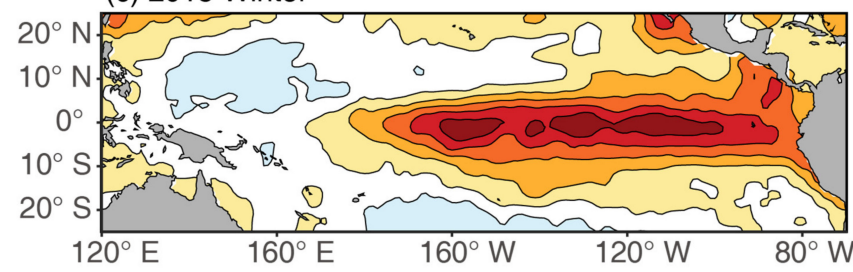

(d) 2016 Spring

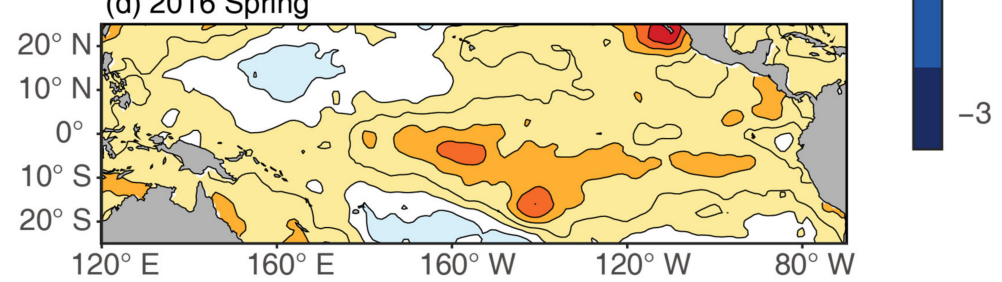

Figure 6. SSTA distributions of 2015-2016 El Niño event during different seasons, unit: ${ }^{\circ} \mathrm{C}$ : (a) summer in 2015, (b) autumn in 2015, (c) winter in 2015, and (d) spring in 2016.

Figure 7a shows the subsurface ocean temperature anomalies (SOTA) evolution of Mix El Niño. The warming maximum of SOTA concentrates near the thermocline, while the cooling SOTA are in western Pacific warm pool region. The warming anomalies widely spread in the mix layer in both central and eastern Pacific. Slightly zonal propagation is found during Mix El Niño. As the location of the thermocline in tropical Pacific is deep in central Pacific and shallow in eastern Pacific. The SSTA are stronger in eastern Pacific than in central Pacific during the developing period (Figure 7a). Along with the evolution of Mix El Niño, the SOTA in central Pacific begin to emerge in the ocean surface, while the SOTA in eastern Pacific decay, resulting in the westward propagation of the SSTA center.

In contrast, the SOTA evolution shows a significant eastward propagation from central Pacific to eastern Pacific during EP El Niño (Figure 7b). The maximum SOTA appear near the thermocline and continuously transport shifts to the far eastern Pacific region, which results in a locked SSTA center over the far eastern Pacific region throughout the whole evolution of EP El Niño. As for CP El Niño (Figure 7c), the SOTA distribution shows a zonal tripolar structure with the warming SOTA mainly in central Pacific, while cooling anomalies in western Pacific and far eastern Pacific region. The zonal propagation of $\mathrm{CP} \mathrm{El}$ Niño is weak and the zonal tripolar distribution of SOTA persists throughout the whole evolution of CP El Niño. During the development period, the Mix El Niño is similar to EP 
El Niño $(-9,-6$, and -3 months lag), but when it reaches the mature and decay periods $(0,3$, and 6 months lag), the widely spread of the SOTA in both central and eastern Pacific makes the Mix El Niño quite unique from the EP and CP El Niño.

(a) Mix El Niño
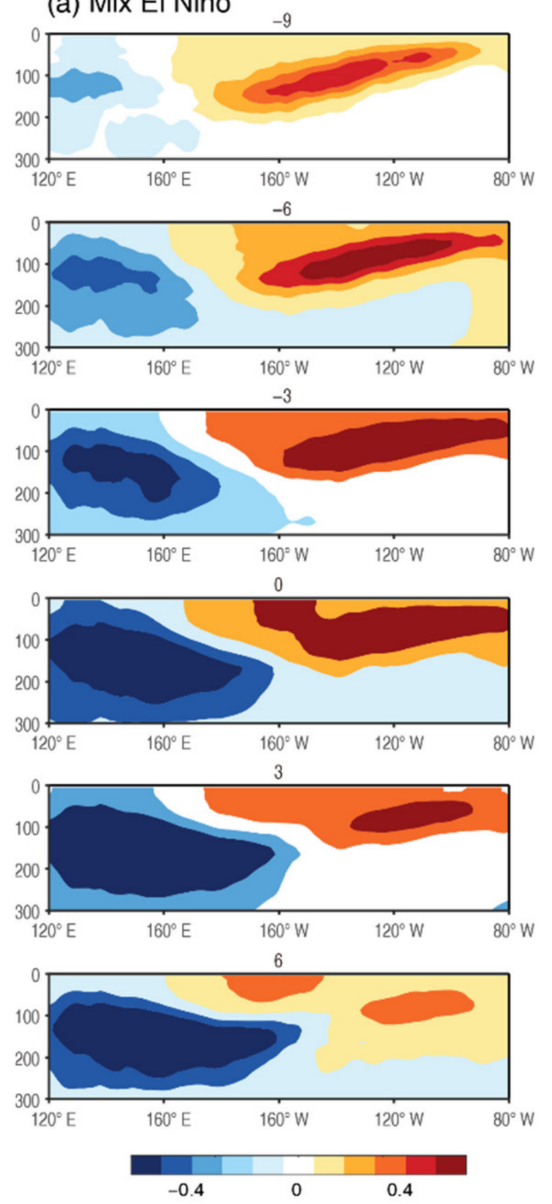

(b) EP El Niño
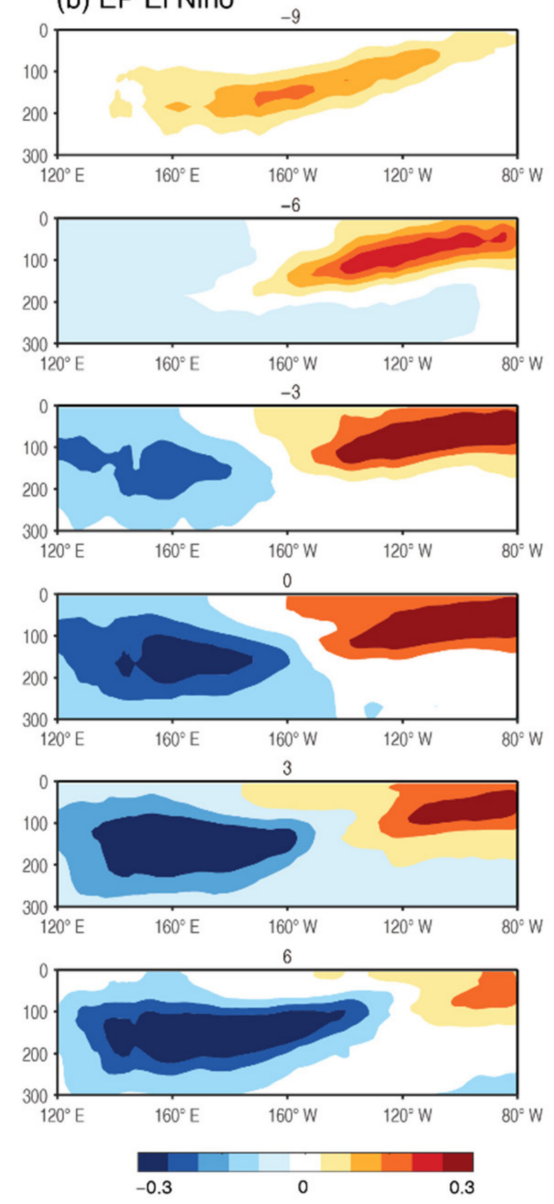

(c) CP EI Niño
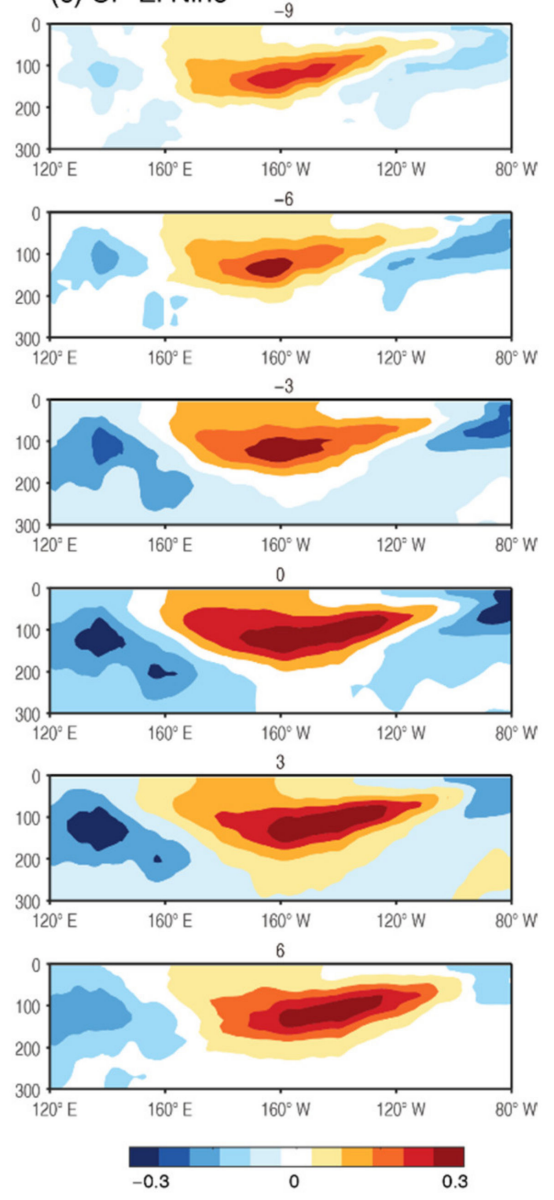

Figure 7. Same as Figure 5, but for subsurface vertical (unit: meter) temperature anomalies averaged of $5^{\circ} \mathrm{S}-5^{\circ} \mathrm{N}$, unit: ${ }^{\circ} \mathrm{C}$.

The sea surface height anomalies (SSHA) evolution of Mix El Niño is shown in Figure 8a. The SSHA data is only available since 1980s, which is too short to cover the research period. Considering there is a linear relationship between SSHA and the change of thermocline depth [39], we use the vertical averaged SOTA between surface and subsurface $300 \mathrm{~m}$ to reflect the change of thermocline depth and further to represent the SSHA evolution. As the figure shows, the positive SSHA during Mix El Niño are mainly in the central and eastern Pacific around equator with a slight eastward propagation and the negative SSHA are located in the western Pacific warm pool. In contrast, the SSHA evolution of EP El Niño (Figure 8b) shows a pronounced eastward propagation from central Pacific to far eastern Pacific, which is a typical equatorial Kelvin wave process. The developing period of EP El Niño is similar to Mix El Niño, but the mature and decaying period is quite different from Mix El Niño. As for CP El Niño (Figure 8c), the SSHA in central Pacific are positive, while in western and far eastern Pacific are negative, which show a typical tripolar structure with little change along with the evolution of CP El Niño. Consistent with the evolutions of SSTA and SOTA, the evolution of SSHA of the Mix El Niño is also similar to the EP El Niño during the development period ( -9 and -6 months lag), but during the mature period (0 lag), the center of the anomalies does not reach the far eastern Pacific region and shows a meridional off-equatorial direction decay in central and eastern Pacific regions (6 months lag), which is quite different from the EP El Niño. 
(a) Mix El Niño
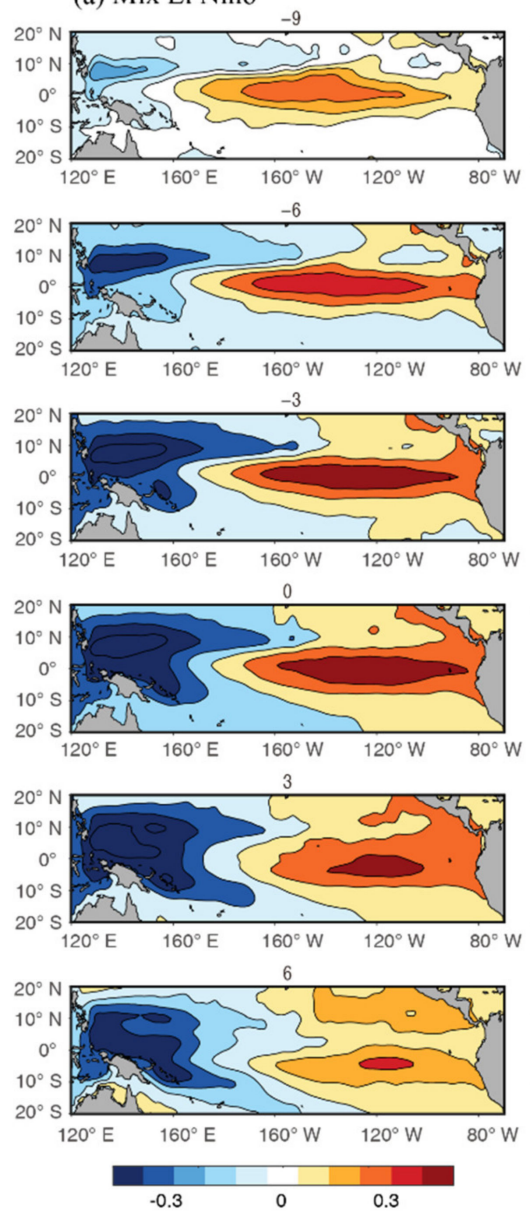

(b) EP El Niño
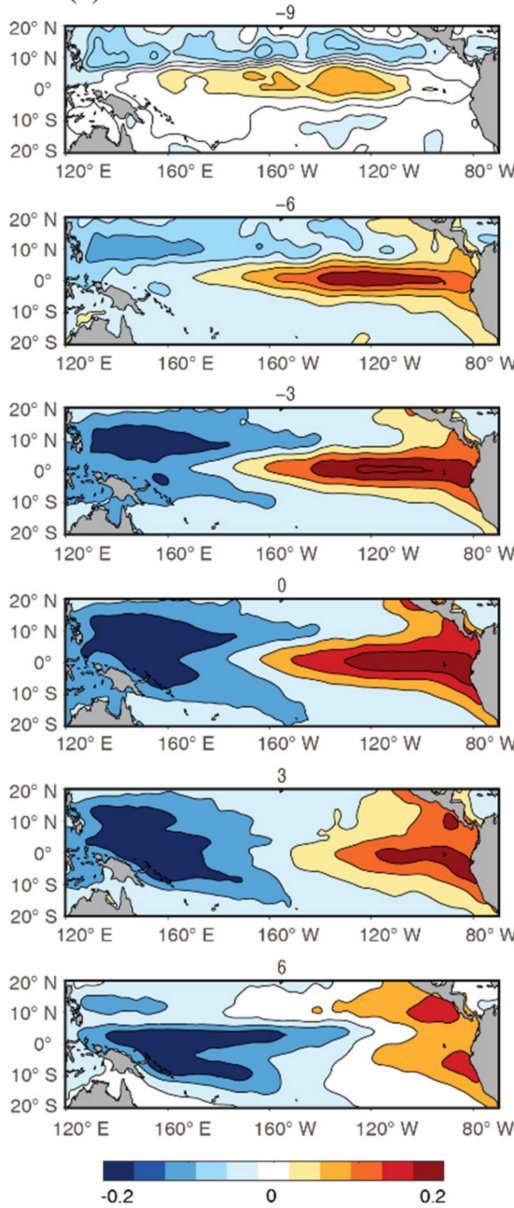

(c) CP El Niño
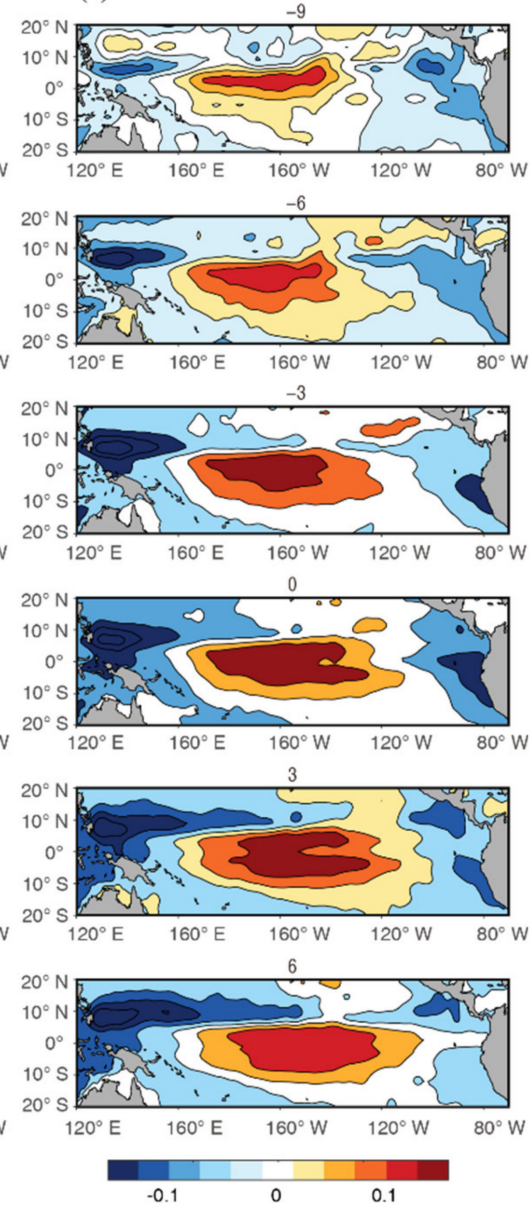

Figure 8. Same as Figure 5, but for sea surface height anomalies, which we used averaged subsurface temperatures of surface to $300 \mathrm{~m}$ depth to represent, unit: ${ }^{\circ} \mathrm{C}$.

The El Niño is accompanied with strong ocean-atmosphere coupled interaction and the ocean-atmosphere coupled interaction processes are quite different among three types of El Niño. From this section, we try to figure out the related ocean-atmosphere coupled interaction of Mix El Niño. Figure 9a demonstrates the evolution of zonal wind shear anomalies, which are calculated by the low level $850 \mathrm{hPa}$ subtracting high level $200 \mathrm{hPa}$ zonal wind anomalies during Mix El Niño. The evolution of 850 and $200 \mathrm{hPa}$ zonal wind anomalies are also examined, and the results of two levels are very similar but with opposite direction (not shown in Figures). The burst of the westerlies at low level is a very important driver for the rise of all three types of El Niño, which delivers the warming water from the western Pacific warm pool to the central and eastern Pacific along the thermocline. The difference among three types of El Niño is mainly in the eastern Pacific region. As Figure 9a shows, the westerlies during Mix El Niño are mainly located in central Pacific region while weak in the eastern Pacific and have little movement. The weak zonal westerlies at low level in the eastern Pacific region may be the key factor that leads to the small zonal gradient of SSTA. According to the Bjerknes positive-feedback mechanism [40], the small zonal SSTA gradient weakens the zonal westerlies, which, in turn, further leads to the smaller zonal SSTA gradient in central-eastern Pacific. In contrast, the strong westerlies of EP El Niño have a significant propagation from the western Pacific to the eastern Pacific. During the decaying period of EP El Niño, the strong zonal westerlies at low level in the eastern Pacific region helps to lock the center of SSTA in the far eastern Pacific region. The high zonal SSTA gradient strengthens the zonal westerlies, which, in turn, further maintain the zonal SSTA gradient of SSTA. As for CP El Niño, except for the westerlies, there are easterlies at low level in the eastern Pacific region. The westerlies deliver warming water 
from western Pacific and the easterlies deliver warming water from the far eastern Pacific to the central Pacific, which results in the tripolar SSTA structure of CP El Niño.

(a) Mix El Niño
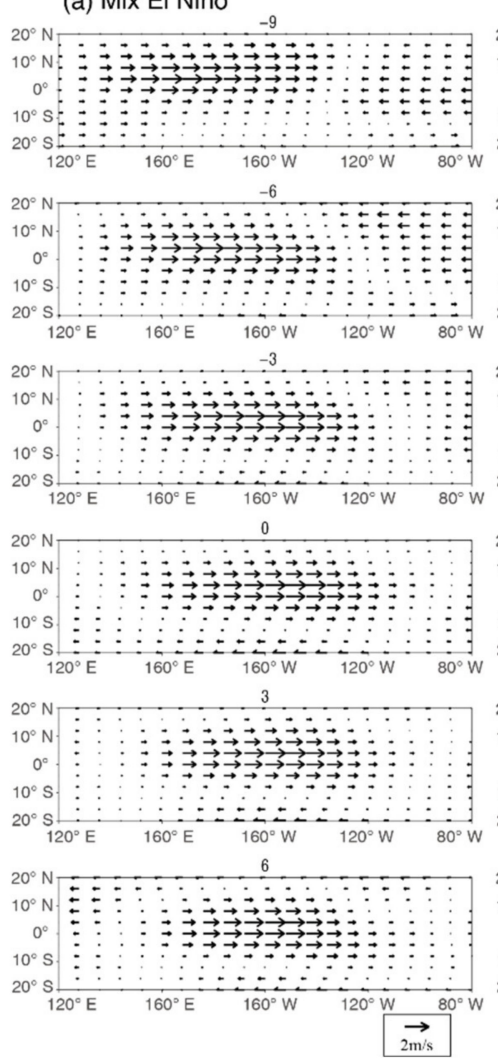

(b) EP El Niño
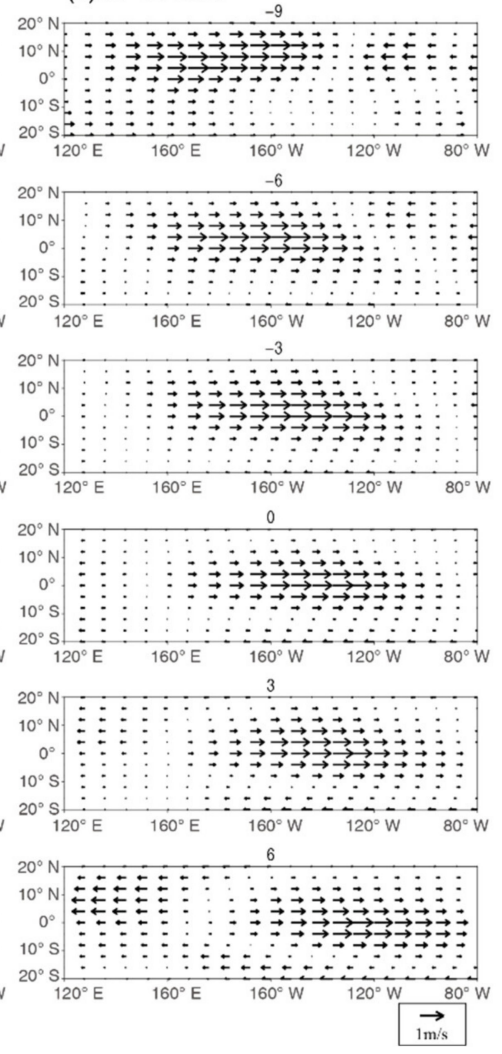

(c) CP El Niño

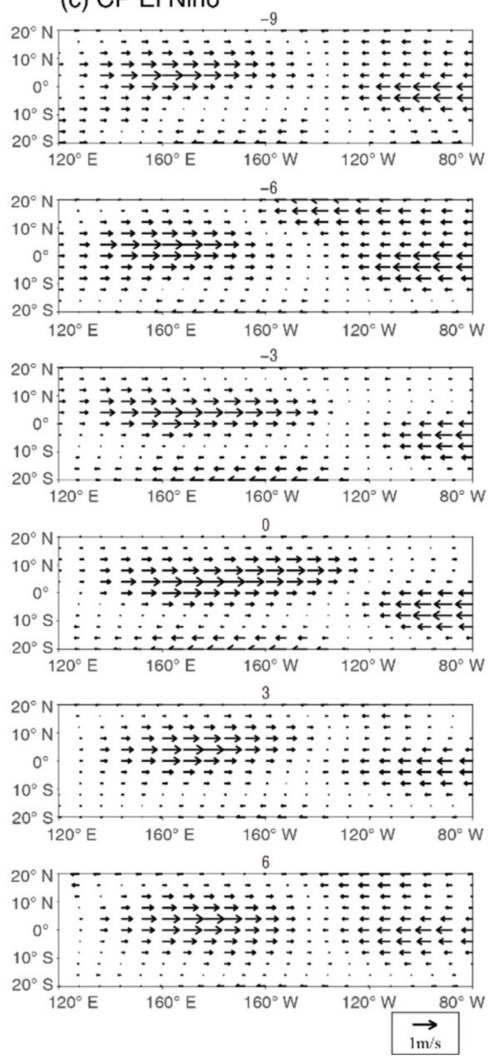

Figure 9. Same as Figure 5, but for the zonal wind shear (850-200 hPa).

The anomalous atmospheric Walker circulation during Mix El Niño is mainly located in the western-central Pacific region (Figure 9a). In contrast, the anomalous atmospheric Walker circulation of EP El Niño during the development period is similar to Mix El Niño but after that extends to the eastern Pacific during the mature and decay periods (Figure 9b). As for CP El Niño (Figure 9c), the anomalous atmospheric Walker circulation in westerncentral Pacific is similar to Mix El Niño, but there is another anomalous atmospheric Walker circulation in eastern-central Pacific. The differences of the anomalous atmospheric Walker circulations among three types of El Niño highly related to the SSTA features of three types of El Niño. The weak anomalous Walker circulation in eastern Pacific finally leads to the weak zonal gradient of SSTA in central-eastern Pacific. In contrast, the eastward extending of the anomalous Walker circulation during EP El Niño helps maintaining the positive high zonal gradient of SSTA and locking the SSTA center in the far eastern Pacific region. As for CP El Niño, the opposite direction anomalous Walker circulation in central-eastern Pacific helps maintaining the negative high zonal gradient of SSTA in central-eastern Pacific and locking the SSTA center in central Pacific.

Figure 10a shows the spatial correlation between $500 \mathrm{hPa}$ vertical upward wind anomalies (omega, contour line) as well as the precipitation anomalies (shaded) and PC1. As the figure shows, the related omega and precipitation anomalies widely spread in both central and eastern Pacific and the maximums are mainly in central Pacific. In contrast, the related omega and precipitation anomalies of EP El Niño are also in central and eastern Pacific, while the maximums are in eastern Pacific (Figure 10b). As for CP El Niño (Figure 10c), there is a dipole pattern in central and eastern Pacific with the upward wind anomalies and increased precipitation in central Pacific and downward wind anomalies and decreased precipitation in eastern Pacific. In the western Pacific and southeast Asia region, 
all three types of El Niño show downward wind anomalies and decreased precipitation. As for the teleconnection impacts, the related increased precipitation of Mix El Niño occurs in the Middle east, Indian Ocean, southeast of China, northeast Pacific, north America and north Atlantic at around $30 \mathrm{~N}$, and southeast Pacific and south America at around $30 \mathrm{~S}$. The related decreased precipitation of Mix El Niño mainly occurs in the south Africa, north and south Pacific, and northern south America. The spatial distribution of the related Omega anomalies of Mix El Niño is consisted with the precipitation anomalies.

(a) Mix El Niño

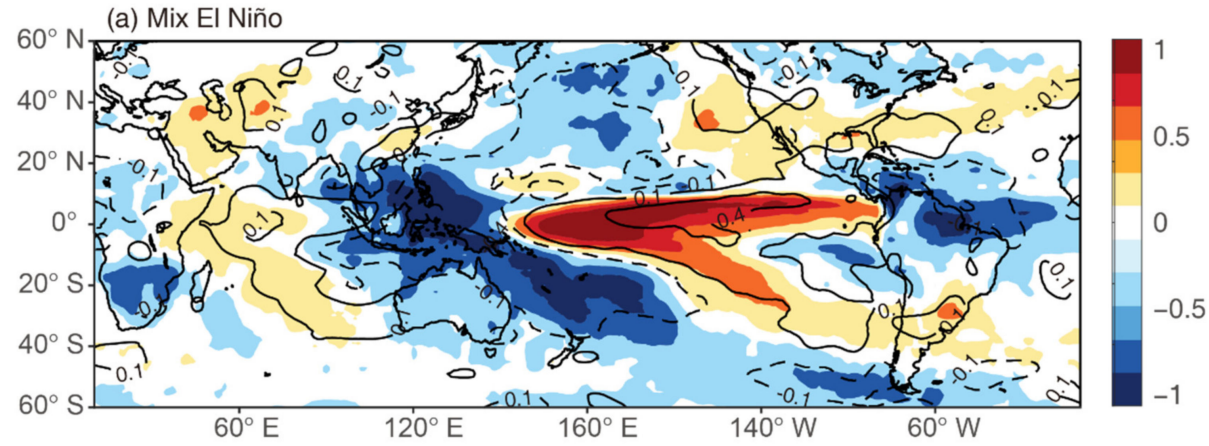

(b) EP El Niño

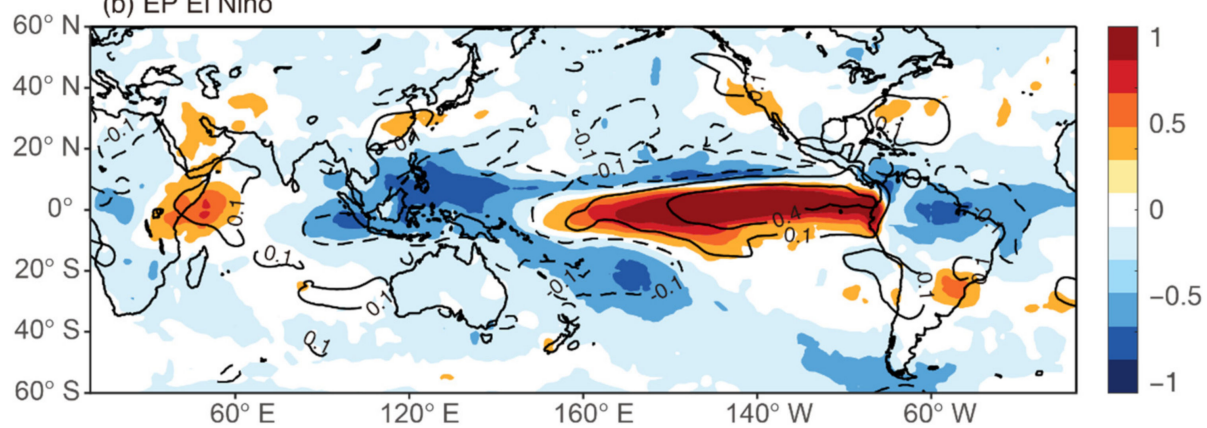

(c) CP EI Niño

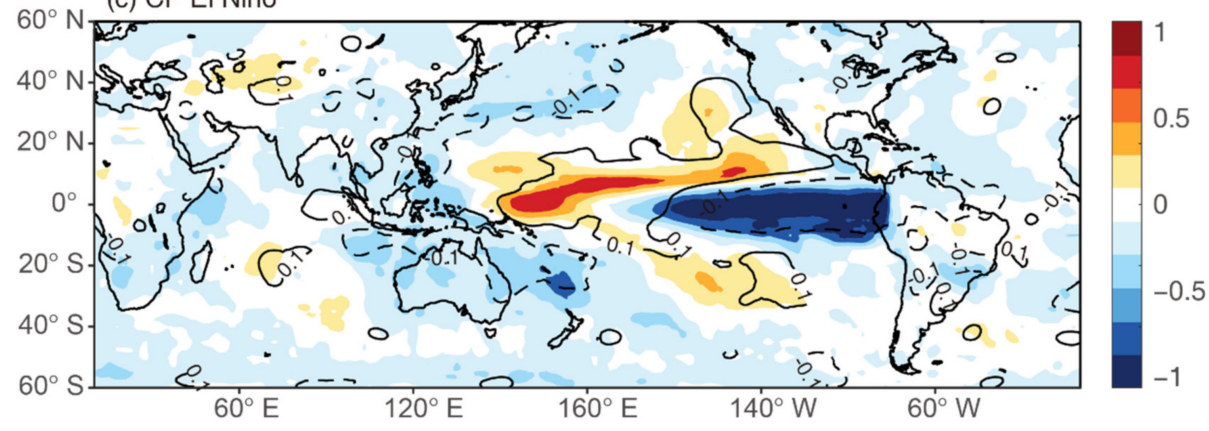

Figure 10. Correlation coefficient between precipitation anomalies (shaded) and $500 \mathrm{hPa}$ vertical wind anomalies (line, positive indicates upward direction) and (a) PC1, (b) EPI, and (c) CPI.

\section{Summary and Discussion}

In this research, the mixed type of El Niño is investigated. The EP and CP El Niño both have a strong zonal SSTA gradient in central-eastern Pacific region, while the zonal SSTA gradient of Mix El Niño is very weak. Based on this unique feature of Mix El Niño, we first removed the SSTA that highly related to the zonal SSTA gradient from the original SSTA field and then applied the EOF analysis on the processed SSTA field (similar to the regression-EOF method used in [9]). Finally, we successfully extracted the Mix El Niño pattern from the tropical Pacific. It is widely believed that the EP El Niño is a traditional type of El Niño. However, our research demonstrates that the Mix El Niño is a more usual El Niño because the frequency of Mix El Niño is much higher than the EP El Niño as well as CP El Niño before the 1980s. The frequency of extreme El Niño may increase under the global warming background [41] and the latest extreme El Niño 2015-2016 is a typical 
Mix El Niño. Whether Mix El Niño will be a tendency of the extreme El Niño still needs further investigation.

The evolution and ocean-atmosphere coupled interaction during Mix El Niño are investigated in this research. The SSTA center of Mix El Niño has a significant westward propagation from the far eastern Pacific to central Pacific. In contrast, the maximum SSTA are locked in the eastern/central Pacific region during EP/CP El Niño. The anomalous atmospheric Walker circulation of Mix El Niño is mainly in western and central Pacific while very weak in eastern Pacific. The weak zonal westerlies in eastern Pacific at low level leads to the small zonal gradient of SSTA and the small gradient of SSTA in turn weakens the westerlies in eastern Pacific. In contrast, the high positive SSTA gradient of EP El Niño is accompanied with strong westerlies in eastern Pacific, and the high negative SSTA gradient of CP El Niño is accompanied with easterlies in eastern Pacific.

In the past research, EP and $\mathrm{CP}$ El Niño are the focus of the attention. As the Mix El Niño rarely appears in recent decades, this type of El Niño has been overlooked to a certain extent. However, the recent 2015-2016 El Niño, which is the first extreme event in the 21st century, is a mixed type of El Niño [28-30]. Many unique physical characters of 2015-2016 El Niño event have been identified, e.g., the westward propagation of the SSTA center [42], which has been proved to be a universal feature of Mix El Niño events in our research. In addition, the climate impacts of 2015-2016 El Niño event are quite different from the previous EP and CP El Niño events. Moreover, the tropical Pacific SST anomaly pattern is very important for regional climate variabilities [43], simulations [44,45], and projections [46,47]. Furthermore, several studies have demonstrated that the Mix El Niño have unique impact on climate, such as global average temperature [48], Indian ocean dipole [49], south American rainfall [50], and summer rainfall in China [51]. Therefore, it is necessary to further investigate the nature as well as the climate impact of Mix El Niño, which will advance the understanding of the El Niño diversity.

Author Contributions: Z.Z. and G.L. designed and organized this research. Z.Z. analyzed the data. Z.Z. and G.L. wrote the manuscript. All authors have read and agreed to the published version of the manuscript.

Funding: This work is supported by the Fundamental Research Funds for the Central Universities (B200202138 and B210201015), the Natural Science Foundation of China (41831175), and the Open fund of State Key Laboratory of loess and Quaternary Geology (520013212).

Institutional Review Board Statement: Not applicable.

Informed Consent Statement: Not applicable.

Data Availability Statement: The datasets used in this study are publicly available online.

Acknowledgments: The authors acknowledge the Met Office Hadley Centre for providing the Hadley Centre Sea Ice and Sea Surface Temperature data set (HadISST), https:/ / www.metoffice. gov.uk/hadobs/hadisst/ (accessed on 7 April 2021)) and EN4: quality controlled subsurface ocean temperature and salinity profiles and objective analyses (version 4.1.1, http:/ /hadobs.metoffice.com/ en4/download-en4-1-1.html (accessed on 7 April 2021)), and the NOAA/OAR/ESRL PSL, Boulder, Colorado, USA, for providing the 20th Century Reanalysis V2c data, NCEP Reanalysis data, and GPCP Precipitation data, from their Web site at https://psl.noaa.gov/ (accessed on 7 April 2021).

Conflicts of Interest: The authors declare no conflict of interest.

\section{References}

1. Trenberth, K.E. The Definition of El Niño. Bull. Am. Meteorol. Soc. 1997, 78, 2771-2777. [CrossRef]

2. Weng, H.; Ashok, K.; Behera, S.K.; Rao, S.A.; Yamagata, T. Impacts of recent El Niño Modoki on dry/wet conditions in the Pacific rim during boreal summer. Clim. Dyn. 2007, 29, 113-129. [CrossRef]

3. Weng, H.; Behera, S.K.; Yamagata, T. Anomalous winter climate conditions in the Pacific rim during recent El Niño Modoki and El Niño events. Clim. Dyn. 2008, 32, 663-674. [CrossRef] 
4. Ye, C.; Deng, L.; Huang, W.-R.; Chen, J. Comparison of the Madden-Julian Oscillation-Related Tropical Cyclone Genesis over the South China Sea and Western North Pacific under Different El Niño-Southern Oscillation Conditions. Atmosphere 2020, 11, 183. [CrossRef]

5. Woo, S.H.; Choi, J.; Jeong, J.H. Modulation of ENSO teleconnection on the relationship between arctic oscillation and wintertime temperature variation in south Korea. Atmosphere 2020, 11, 950. [CrossRef]

6. Rasmusson, E.M.; Carpenter, T.H. Variations in Tropical Sea Surface Temperature and Surface Wind Fields Associated with the Southern Oscillation/El Niño. Mon. Weather Rev. 1982, 110, 354-384. [CrossRef]

7. Yeh, S.; Kug, J.; Dewitte, B.; Kwon, M.; Kirtman, B.P.; Jin, F.-F. El Niño in a changing climate. Nature 2009, 461, 511-514. [CrossRef]

8. Trenberth, K.E.; Stepaniak, D.P. Indices of el Niño evolution. J. Clim. 2001, 14, 1697-1701. [CrossRef]

9. Yu, J.-Y.; Kao, H.-Y. Contrasting Eastern-Pacific and Central-Pacific Types of ENSO. J. Clim. 2009, 22, 615-632.

10. Jin, F.-F.; Kug, J.-S.; An, S.-I. Two Types of El Niño Events: Cold Tongue El Niño and Warm Pool El Niño. J. Clim. 2009, 22, 1499-1515.

11. Ashok, K.; Behera, S.K.; Rao, S.A.; Weng, H.; Yamagata, T. El Niño Modoki and its possible teleconnection. J. Geophys. Research 2007, 112, C11007. [CrossRef]

12. Ren, H.-L.; Jin, F.-F. Niño indices for two types of ENSO. Geophys. Res. Lett. 2011, 38. [CrossRef]

13. Larkin, N.K.; Harrison, D.E. Global seasonal temperature and precipitation anomalies during El Niño autumn and winter. Geophys. Res. Lett. 2005, 32, L13705. [CrossRef]

14. Jinshuang, Z.; Yudi, L.; Ruiqing, X.; Haijie, C. A comparative analysis of the impacts of two types of El Niño on the central and eastern Pacific ITCZ. Atmosphere 2018, 9, 266.

15. Cai, W.; Wu, L.; Lengaigne, M.; Li, T.; McGregor, S.; Kug, J.-S.; Yu, J.-Y.; Stuecker, M.; Santoso, A.; Li, X.; et al. Pantropical climate interactions. Science 2019, 363, eaav4236. [CrossRef] [PubMed]

16. Liu, Y.; Li, S. North-South Discrepancy of Interannual Sea Surface Temperature Anomalies over the South China Sea Associated with Eastern Pacific El Niño Events in the Spring. Atmosphere 2020, 11, 1135. [CrossRef]

17. Li, G.; Ren, B.; Yang, C.; Zheng, J. Indices of El Niño and El Niño Modoki: An improved El Niño Modoki index. Adv. Atmos. Sci. 2010, 27, 1210-1220. [CrossRef]

18. Ashok, K.; Yamagata, T. The El Niño with a difference. Nat. Clim. Chang. 2009, 461, 481-484. [CrossRef]

19. Marathe, S.; Ashok, K.; Swapna, P.; Sabin, T.P. Revisiting El Niño Modoki. Clim. Chang. 2015, 45, 3527-3545. [CrossRef]

20. Chen, D.; Lian, T.; Fu, C.; Cane, M.A.; Tang, Y.; Murtugudde, R.; Song, X.; Wu, Q.; Zhou, L. Strong influence of westerly wind bursts on El Niño diversity. Nat. Geosci. 2015, 8, 339-345. [CrossRef]

21. Yu, J.-Y.; Kim, S.T. Identifying the types of major El Niño events since 1870. Int. J. Climatol. 2013, 33, 2105-2112. [CrossRef]

22. Zhang, Z.; Ren, B.; Zheng, J. A unified complex index to characterize two types of ENSO simultaneously. Sci. Rep. 2019, 9, 8373. [CrossRef]

23. Abellán, E.; McGregor, S.; England, M.H.; Santoso, A. Distinctive role of ocean advection anomalies in the development of the extreme 2015-16 El Niño. Clim. Dyn. 2017, 51, 2191-2208. [CrossRef]

24. Hu, S.; Fedorov, A.V. The extreme El Niño of 2015-2016 and the end of global warming hiatus. Geophys. Res. Lett. 2017, 44, 3816-3824. [CrossRef]

25. Paek, H.; Yu, J.-Y.; Qian, C. Why were the 2015/2016 and 1997/1998 extreme El Niño different? Geophys. Res. Lett. 2017. [CrossRef]

26. Santoso, A.; McPhaden, M.J.; Cai, W. The Defining Characteristics of ENSO Extremes and the Strong 2015/2016 El Niño. Rev. Geophys. 2017, 55, 1079-1129. [CrossRef]

27. Chen, L.; Li, T.; Wang, B.; Wang, L. Formation Mechanism for 2015/16 Super El Niño. Sci. Rep. 2017, 7, 2975. [CrossRef] [PubMed]

28. Lin, P.; Held, I.; Ming, Y. The Early Development of the 2015/16 Quasi-Biennial Oscillation Disruption. J. Atmos. Sci. 2019, 76, 821-836. [CrossRef]

29. Zhong, W.; Cai, W.; Zheng, X.T.; Yang, S. Unusual Anomaly Pattern of the 2015/2016 Extreme El Niño Induced by the 2014 Warm Condition. Geophys. Res. Lett. 2019, 46, 14772-14781. [CrossRef]

30. Wu, Y.K.; Hong, C.C.; Chen, C.T. Distinct Effects of the Two Strong El Niño Events in 2015-2016 and 1997-1998 on the Western North Pacific Monsoon and Tropical Cyclone Activity: Role of Subtropical Eastern North Pacific Warm SSTA. J. Geophys. Res. Oceans 2018, 123, 3603-3618. [CrossRef]

31. Kim, H.-M.; Webster, P.J.; Curry, J.A. Impact of shifting patterns of Pacific Ocean warming on North Atlantic tropical cyclones. Science 2009, 325, 77-80. [CrossRef] [PubMed]

32. Rayner, N.A.; Parker, D.E.; Horton, E.B.; Folland, C.K.; Alexander, L.V.; Rowell, D.P.; Kent, E.C.; Kaplan, A. Global analyses of sea surface temperature, sea ice, and night marine air temperature since the late nineteenth century. J. Geophys. Res. 2003, $108,4407$. [CrossRef]

33. Good, S.A.; Martin, M.J.; Rayner, N.A. EN4: Quality controlled ocean temperature and salinity profiles and monthly objective analyses with uncertainty estimates. J. Geophys. Res. Oceans 2013, 118, 6704-6716. [CrossRef]

34. Kistler, R.; Kalnay, E.; Collins, W.; Saha, S.; White, G.; Woollen, J.; Chelliah, M.; Ebisuzaki, W.; Kanamitsu, M.; Kousky, V.; et al. The NCEP-NCAR 50-Year Reanalysis: Monthly Means CD-ROM and Documentation. Bull. Am. Meteor. Soc. 2001, 82, 247-268. [CrossRef] 
35. National Center for Atmospheric Research Staff (Ed.) The Climate Data Guide: NOAA 20th-Century Reanalysis, Version 2 and 2c. Last Modified 12 December 2019. Available online: https:/ / climatedataguide.ucar.edu/climate-data/noaa-20th-centuryreanalysis-version-2-and-2c (accessed on 7 April 2021).

36. Adler, R.F.; Huffman, G.J.; Chang, A.; Ferraro, R.; Xie, P.; Janowiak, J.; Rudolf, B.; Schneider, U.; Curtis, S.; Bolvin, D.; et al. The Version 2 Global Precipitation Climatology Project (GPCP) Monthly Precipitation Analysis (1979-Present). J. Hydrometeor. 2003, 4, 1147-1167. [CrossRef]

37. Li, G.; Ren, B.-H.; Yang, C.-Y. Traditional El Niño and El Niño Modoki revisited: Is El Niño Modoki linearly independent of traditional El Niño? Atmos. Ocean. Sci. Lett. 2010. [CrossRef]

38. Yu, J.Y.; Kao, H.Y.; Lee, T.; Kim, S.T. Subsurface ocean temperature indices for central-pacific and eastern-pacific types of El Niño and La Nina events. Theor. Appl. Climatol. 2011, 103, 337-344. [CrossRef]

39. Chelton, D.B.; Schlax, M.G. Global observations of oceanic Rossby waves. Science 1996, 292, 234. [CrossRef]

40. Bjerknes, J.A. Atmospheric teleconnections from the equatorial pacific. Mon. Weather Rev. 1969, 97, 163-172. [CrossRef]

41. Cai, W.; Wang, G.; Santoso, A. Stronger Increase in the Frequency of Extreme Convective than Extreme Warm El Niño Events under Greenhouse Warming. J. Clim. 2020, 33, 675-690.

42. Ren, H.L.; Wang, R.; Zhai, P.; Ding, Y.; Lu, B. Upper-ocean dynamical features and prediction of the super El Niño in 2015/16: A comparison with the cases in 1982/83 and 1997/98. J. Meteorol. Res. 2017, 31, 278-294. [CrossRef]

43. Li, G.; Gao, C.; Lu, B.; Chen, H. Inter-annual variability of spring precipitation over the Indo-China Peninsula and its asymmetric relationship with El Niño-Southern Oscillation. Clim. Dyn. 2021. [CrossRef]

44. Li, G.; Du, Y.; Xu, H.; Ren, B. An Intermodel Approach to Identify the Source of Excessive Equatorial Pacific Cold Tongue in CMIP5 Models and Uncertainty in Observational Datasets. J. Clim. 2015, 28, 7630-7640. [CrossRef]

45. Li, G.; Jian, Y.; Yang, S.; Du, Y.; Wang, Z.; Li, Z.; Zhuang, W.; Jiang, W.; Huang, G. Effect of excessive equatorial Pacific cold tongue bias on the El Niño-Northwest Pacific summer monsoon relationship in CMIP5 multimodel ensemble. Clim. Dyn. 2019, 52, 6195-6212. [CrossRef]

46. Li, G.; Xie, S.-P.; Du, Y.; Luo, Y. Effect of excessive equatorial cold tongue bias on the projections of the tropical Pacific climate change. Part I: The warming pattern in CMIP5 multi-model ensemble. Clim. Dyn. 2016, 47, 3817-3831. [CrossRef]

47. Li, G.; Xie, S.-P.; He, C.; Chen, Z. Western Pacific emergent constraint lowers projected increase in Indian summer monsoon rainfall. Nat. Clim. Chang. 2017, 7, 708-712. [CrossRef]

48. Banholzer, S.; Donner, S. The influence of different El Niño types on global average temperature. Geophys. Res. Lett. 2014, 41, 2093-2099. [CrossRef]

49. Zhang, W.; Wang, Y.; Jin, F.-F.; Stuecker, M.F.; Turner, A.G. Impact of different El Niño types on the El Niño/IOD relationship. Geophys. Res. Lett. 2015, 42, 8570-8576. [CrossRef]

50. Andreoli, R.V.; Oliveira, S.; Kayano, M.T.; Viegas, J.; Souza, R.A.F.D.; Candido, L.A. The influence of different El Niño types on the south American rainfall. Int. J. Climatol. 2016, 37. [CrossRef]

51. Yuan, Y.; Yang, H.; Li, C. Study of El Niño events of different types and their potential impact on the following summer precipitation in China. Acta Meteorol. Sin. 2012, 70, 467-478. 